\title{
AAUTORIA FEMININA NA LITERATURA PORTUGUESA: REFLEXÕES SOBRE AS TEORIAS DO CÂNONE, de Fabio Mario da Silva. Lisboa: Edições Colibri, 2014.
}

\section{Henrique Marques Samyn* UERJ}

Pesquisador que vem consolidando sua posição entre aqueles que se dedicam aos estudos em torno da literatura portuguesa de autoria feminina, Fabio Mario da Silva publica neste volume parte da pesquisa que resultou em sua tese de doutorado, defendida na Universidade de Évora em 2013, e que teve a orientação de Ana Luísa Vilela e a coorientação de António Cândido Franco e Maria Lúcia Dal Farra. Considerando-se que, em anos anteriores, Fabio Mario dedicara-se à pesquisa em torno de autoras como Virgínia Victorino, Judith Teixeira e, principalmente, Florbela Espanca centro de sua investigação durante o mestrado, do qual resultou a dissertação também publicada em livro: Da metacrítica à psicanálise: a angústia do “eu” lírico na poesia de Florbela Espanca (João Pessoa: Ideia, 2009) -, a mais recente publicação assinala o profícuo aprofundamento de uma reflexão que avança dos estudos de casos particulares para a crítica das estruturas que, no decorrer do processo histórico, determinaram o apagamento de mulheres que se dedicaram à produção literária.

No texto introdutório ao volume, Fabio Mario delineia o percurso em que busca concretizar suas reflexões, a partir da questão que o inquieta - assim por ele próprio caracterizada: “o que se nota na maior parte das histórias da literatura ocidentais é um desprestígio constante da produção literária de autoria feminina, que parece continuamente deixar as mulheres escritoras à margem da literatura oficial” (p. 13). Trata-se, por conseguinte, de abordar um conjunto de questionamentos que tangenciam aspectos fulcrais do modo como operam os processos de estruturação do cânone literário; contudo, evidenciando o intento de não limitar-se a essa reflexão teórica, já nas considerações iniciais o autor explicita que sua investigação abarcou também a realização de um inquérito com professores universitários europeus e brasileiros, visando a recensear de que modo a autoria feminina vem sendo valorada nos âmbitos de formação de futuros professores e leitores, e o estudo de um conjunto de escritoras que produziram suas obras entre os séculos XVI e XIX, assim buscando colaborar para o preenchimento de lacunas persistentes no que tange ao estudo de autoras nascidas antes do século XX. Dedicarei os próximos parágrafos a analisar os capítulos centrais do volume.
${ }^{*}$ Professor Adjunto de Literatura Portuguesa na Universidade do Estado do Rio de Janeiro (ILE-UERJ). marquessamyn@ gmail.com 
Em “Cânone e sub(o)missão”, Fabio Mario da Silva submete a escrutínio a noção de cânone literário; seu ponto de partida é a definição apresentada por Harold Bloom em O cânone ocidental, cujas inconsistências e contradições, já destacadas por diversos teóricos e intelectuais, são evocadas a fim de contextualizar de que modo os mecanismos de estruturação canônica da literatura vêm sendo questionados tanto a partir de debates derivados da afirmação de movimentos políticos desde o início do século XX quanto pela emergência de novas perspectivas no âmbito dos estudos literários. Em decorrência disso, ao reconhecimento da importância ou da necessidade do cânone impõe-se a crítica em torno dos critérios subjacentes à seleção das obras que dele fazem parte; “entende-se assim que o cânone literário não vive apenas do passado, mas é a partir desse passado que se cria uma linha imaginária - assintótica - na qual perpassam obras e autores, que narram, dramatizam ou poetizam de maneira muito própria, no interior do seu contexto, servindo como ponte comparativa de pensamento entre as novas estéticas literárias e as que já foram referências outrora, delimitando as relações de pensamento de uma nação, ou de um período histórico”, observa o autor (p. 34). Não obstante, uma vez submetido a questionamentos dessa ordem, o conceito de cânone acaba por ensejar considerações em torno dos diferentes processos que o estruturam - de onde deriva, por exemplo, a distinção entre o “canonicidade estática” e a “canonicidade dinâmica”, proposta por Itamar Even-Zohar-, bem como acerca da possibilidade de construção de cânones alternativos - como a ideia de um "contracânone feminista”, proposta por Lilian Robinson.

As reflexões apresentadas no capítulo inicial fornecem elementos para que Fabio Mario problematize de que modo a universidade contribui para o funcionamento do cânone, assunto sobre o qual se debruça em "Análises estatísticas: o cânone e a disciplina de Literatura Portuguesa”. Está aí, a meu ver, uma das mais relevantes contribuições da investigação, sobretudo por conta da maneira como o problema foi abordado: a realização do já mencionado inquérito, aplicado a professores de universidades do Brasil, de Portugal e de outros países europeus. Visando a identificar autores e autoras percebidos(as) como representativos(as) da cultura portuguesa, preferidos(as) por docentes, mais referidos(as) por gênero literário, bem como conhecer a opinião de docentes sobre a literatura produzida por mulheres, Fabio Mario da Silva concebeu um questionário composto por oito questões: em algumas, solicitava a menção de autores ou autoras que interessavam a docentes por razões acadêmicas ou pessoais, inscritos(as) em determinado recorte histórico ou associados(as) a um gênero literário específico; em outras, indagava sobre as opiniões do(a) entrevistado(a) sobre a literatura produzida por mulheres e os estudos de gênero. Como esclarece o pesquisador, seus objetivos eram: identificar autores(as) considerados mais representativos(as) para a Literatura Portuguesa, bem como os(as) preferidos(as) por leitores(as); averiguar os(as) autores(as) mais citados por gênero literário; identificar os 
estereótipos aplicados à produção literária de autoria feminina e as posições em torno da literatura produzida por mulheres portuguesas.

Alcançando respostas de 44 sujeitos - 15 brasileiros, 14 portugueses e 15 pertencentes a quadros docentes de outras universidades europeias -, Fabio Mario da Silva obteve um valioso retrato do estado atual da recepção da literatura produzida por mulheres portuguesas no âmbito acadêmico. De modo necessariamente sucinto, destacarei aqui algumas de suas conclusões. Como esperado, quando indagados sobre nomes representativos da cultura portuguesa, respondentes do inquérito referiram principalmente autores homens (248, em contraste com 13 mulheres); discrepância que se mantém quando são indagados sobre autores(as) de sua preferência, ainda que nesse caso mais mulheres sejam mencionadas (37, em comparação com 220 homens). Observa pesquisador que "o grupo europeu refere mais mulheres do que o português e o brasileiro, sendo que, neste último, os grupos constituídos por sujeitos do sexo feminino são os que citam mais escritores, e os de sexo masculino não citam nenhuma escritora” (p. 69). As perguntas em torno das opiniões sobre a literatura de autoria feminina, embora demonstrem alguma disposição para o reconhecimento de mulheres como produtoras de uma literatura de qualidade, por vezes reitera ainda um conjunto de estereótipos - vinculando suas obras a determinadas características estilísticas (o discurso intimista ou sentimental), por exemplo, ou a temas autobiográficos; de outro lado, a tendência a desvincular o texto literário do gênero do autor é sobretudo constatada nos depoimentos masculinos, algo que acaba por contribuir para o apagamento da especificidade da autoria feminina, sustentando o cânone como uma estrutura fundamentalmente androcêntrica.

O capítulo que encerra o livro, de título "O cânone, a escritora e a construção da Literatura Portuguesa”, pretende discutir de maneira concreta os princípios de estruturação canônica vigentes no caso da literatura lusitana. Demonstração clara da influência de elementos políticos nessas estruturas é o impacto decorrente da Revolução de 1974, que abre espaço para a inclusão de escritoras no sistema educativo; assim, passam a figurar nos planos de ensino autoras como a Marquesa de Alorna, Florbela Espanca, Natália Correia, Maria Teresa Horta, Augustina Bessa-Luís, Fiama Hasse Pais Brandão e Sophia de Mello Breyner Andresen. No mesmo capítulo, Fabio Mario da Silva apresenta uma breve introdução a representações de mulheres na história da Literatura Portuguesa, como preâmbulo a seções dedicadas à análise de autoras nascidas nos séculos XV (Joana da Gama e Públia Hortênsia de Castro), XVII (Bernarda Ferreira de Lacerda, Mariana de Luna e Soror Violante do Céu), XVIII (Soror Maria do Céu, Teresa Margarida Orta e Silva e Teresa de Melo Breyner) e XIX (Ana Augusta Plácido, Judith Teixeira, Florbela Espanca e Virgínia Victorino), analisando textos literários e percorrendo criticamente a recepção de suas obras. 
A autoria feminina na Literatura Portuguesa constitui, em síntese, um trabalho de indiscutível relevância, por abordar de forma perspicaz e inovadora uma questão cuja premência vem sendo cada vez mais reconhecida na contemporaneidade. Como demonstra Fabio Mario da Silva, as produções literárias de autoria feminina permanecem não apenas pouco valorizadas, como também continuam a ser lidas desde perspectivas estereotipadas; e apenas o estímulo para trabalhos investigativos em profundidade, que logrem ultrapassar concepções sedimentadas e superficiais em torno das mulheres escritoras, poderá modificar esse cenário, resgatando e relevando de modo mais adequado a importância da participação feminina na construção da Literatura Portuguesa. 